\title{
Diatom assemblages from the sediment traps in Lake Onega: preliminary results
}

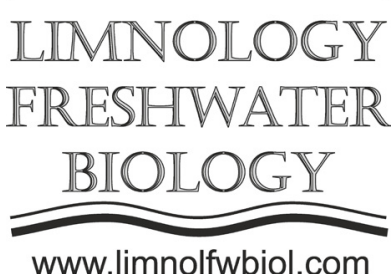

\author{
Ludikova A.V. ${ }^{1 *}$, Belkina N.A. ${ }^{2}$, Strakhovenko V.D. ${ }^{3}$, Subetto D.A. ${ }^{4,2}$, Potakhin M.S. ${ }^{2}$ \\ ${ }^{1}$ Institute of Limnology, Russian Academy of Sciences, Sevastyanova str. 9, St. Petersburg 196105, Russia \\ ${ }^{2}$ Northern Water Problems Institute, Karelian Research Centre, Alexander Nevsky pr. 50, Petrozavodsk, 185910, Karelia, Russia \\ ${ }^{3}$ V.S. Sobolev Institute of Geology and Mineralogy, Siberian Branch Russian Academy of Sciences, Akademika Koptuga pr. 3, Novosibirsk, \\ 30090, Russia \\ ${ }^{4}$ Herzen State Pedagogical University of Russia, Moika 48, St. Petersburg, 191186, Russia
}

\begin{abstract}
A pioneer study of the sediment-trap diatom assemblages in Lake Onega revealed the similarity of their species composition to the living communities, although the taxa with fragile frustules are underrepresented. We suggest that the diatom assemblages composition also reflects some local specifics of the study site (e.g. the intensity of anthropogenic pressure, vegetation development, bottom topography, etc).
\end{abstract}

Keywords: diatoms, sediment traps, Lake Onega

\section{Introduction}

Studying the patterns of sedimentation processes is essential for understanding the current state of the lake ecosystems and predicting future environmental changes. A pioneer study of the sediment-trap diatom assemblages in Lake Onega was performed as a part of the research aimed at assessing the spatial and temporal distribution of sedimentary particles in different part of the Lake Onega basin. The sediment-traps diatom assemblages accumulated during a certain period provide an integrated characteristic of the present-day diatom flora of the lake. Comparing their composition with the living diatom communities contributes to understanding the sedimentation processes, and enables assessing the current state of the lake ecosystem.

\section{Materials and methods}

The study sites are located in different parts of Lake Onega (the Petrozavoskaya, Kondopogskaya, Bolshoe Onego, Lizhemskaya, Unitskaya, Maloe Onego, Zaonezhskiy and Povenetskiy bays, and in the southern open-water part of the lake). The water depth at the stations ranges from 12 to $96 \mathrm{~m}$. 12 sediment traps were installed at $1 \mathrm{~m}$ from the bottom and exposed for 1 year (2018-2019). The samples treatment for the diatom analysis was performed using the standard procedure (Davydova, 1985).

\section{Results and discussion}

Planktonic diatoms prevail in all 12 sites (6192\%). The most widespread and abundant species include Aulacoseira islandica (16-45\%) u A. subarctica (13-42\%). A. islandica, a neutrophilous species known to thrive under the wide range of trophic conditions, predominates in the spring phytoplankton in Lake Onega (Petrova, 1971; Vislyanskaya, 1999; Chekryzheva, 2015), while in some parts of the lake it is also abundant in autumn (Petrova, 1971). Aulacoseira subarctica (previously also identified as Aulacoseira (Melosira) distans var alpigena (A. alpigena), A. italica, or A. italica ssp subarctica) co-dominates A. islandica in the spring phytoplankton (Petrova, 1971; Chekryzheva, 2015). It prefers oligo-mesotrophic environments, and its drastic increase was recorded in the Kondopogskaya Bay sediments as a result of eutrophication (Vasilieva, 1999). In the sediment-trap diatom assemblages, however, the highest proportions of this species were observed in the Petrozavoskaya, Bolshoe Onego and Lizhemskaya bays. In the Kondopogskaya Bay, in turn, eutrophic $A$. ambigua was highly abundant (24-32\%), apparently reflecting higher phosphorous load to this part of Lake Onega.

Previous studies also reported the increased contribution of Diatoma tenuis, Fragilaria crotonensis and Stephanodiscus hantzschii to the phytoplankton assemblages at the areas with highest anthropogenic pressure, such as Petrozavoskaya and Kondopogskaya bays (Chekryzheva, 2012; 2015). In the sediment traps, 
however, these species are rather uncommon, and their proportion rarely exceeds $1 \%$. It could be partly explained by their fragile valves that could already start dissolving in the water column after the cell death. On the other hand, it might also somehow reflect their contribution to the living communities at least during the study period, thus suggesting decreased human impact on the Lake Onega ecosystem compared to the recent past.

Benthic diatoms contribute to $8-39 \%$ of the total diatoms reflecting their secondary role in the sedimenttrap diatom assemblages. They are dominated by epiphytes (8-33\%) with Tabellaria fenestrata being the most common species, abundant in all study sites (6-13\%) except for the Kondopogskaya Bay where it only accounts for $<3 \%$. T. fenestrata, the most widespread species in epiphytic diatom communities in Lake Onega, is also common in summer and autumn planktonic assemblages due to the transportation of its long-chain colonies from the shallow-water parts of the lake where it growths on macrophytes (Petrova, 1971). Highest abundances of epiphytes ( $>20 \%$ ) were observed in the sediment traps from Lizhemskaya, Unitskaya, Maloe Onego, Zaonezhskiy and Povenetskiy bays, where the largest areas of the littoral zone are occupied by macrophytes (Onezhskoe..., 2010). Surprisingly, the highest abundances of both epiphytic and bottom-living diatoms (33\% and 6\%, respectively) were found at the deepest station, the Povenetskiy Bay (96 m). Apparently, it results from the complex bottom topography of this remote sheltered bay, where higher water transparency favors growth of the benthic species in the littoral zone, which are later transported to the deepest part of the basin.

\section{Conclusions}

The preliminary results of the study of the sediment-trap diatom assemblages in Lake Onega demonstrated that:

1. the composition of the most abundant species generally reflects the composition of the most abundant taxa in the living communities;

2. the specifics of the diatom assemblages composition are thought to result from the local specifics of the study sites, such as anthropogenic pressure, macrophytes stocks, water transparency, bottom topography, etc.;

3. the species indicative of eutrophication are underrepresented in the sediment-trap diatom assemblages, which might reflect both their poor preservation and their minor contribution to the living communities at least during the study period.

\section{Acknowledgments}

Research of A. Ludikova contributes to the State Research Program of the Institute of Limnology, RAS, No 0154-2019-0001 (studying the lakes at the catchment area of Lake Ladoga). The study is supported by RFBR grant № 19-05-50014 and RSF grant N 18-17-00176.

\section{References}

Chekryzheva T.A. 2012. Taxonomic and ecological characteristics of phytoplankton in Lake Onega. Trudy Karelskogo nauchnogo tsentra RAN [Proceedings of the Karelian Research Center, RAS] 1: 56-69. (In Russian)

Chekryzheva T.A. 2015. Diatoms in the plankton of Lake Onego. Trudy Karelskogo nauchnogo tsentra RAN [Proceedings of the Karelian Research Center, RAS] 4: 110-116. DOI: 10.17076/bg10 (In Russian)

Davydova N.N. 1985. Diatoms as indicators of Holocene lake environments. Leningrad: Nauka. (In Russian)

Onezhskoe ozero: Atlas [Atlas of Lake Onega]. 2010. In: Filatov N.N. (Ed.) Petrozavodsk: KarNC RAN. (In Russian)

Petrova N.A. 1971. Phytoplankton of Lake Onega. In: The vegetation of Lake Onega. Leningrad: Nauka, pp. 88-129. (In Russian)

Vasilieva E.P. 1999. Present state of bottom sediments. Onega Lake. Ecological problems. Petrozavodsk, pp. 126-142 (In Russian)

Vislyanskaya I.G. 1999. Structure and dynamics of phytoplankton biomass. Lake Onega. Ecological problems. Petrozavodsk: KarRC RAN, pp. 146-158. (In Russian) 